\title{
KORELASI ANTARA RASIO NEUTROFIL LIMFOSIT DENGAN VOLUME INFARK SEREBRI PADA PENDERITA STROKE ISKEMIK AKUT
}

\author{
CORRELATION BETWEEN NEUTROFIL LIMPHOCYTE RATIO AND \\ CEREBRAL INFARCTION VOLUME IN ACUTE ISCHAEMIC STROKE
}

Ilsa Hunaifi, * Triana Dyah Cahyawati**

\begin{abstract}
Introduction: Inflammation plays a key role in stroke pathophysiology. Neutrophils is one of the earliest leucocyte subtypes to infiltrate the ischemia area of the brain. The neutrophil-lymphocyte ratio (NLR) is independent of the severity of coronary heart disease and as a predictor of poor clinical outcomes in patients with coronary heart disease undergoing angiography. The neutrophil-lymphocyte ratio values may be a prognostic factor in ischemic stroke patients. The neutrophillymphocyte ratio values can also be used in predicting infarct size, however limited study has been conducted in this area.

Aim: To determine the correlation of NLR with cerebral infarct volume in acute ischemic stroke patients.

Method: This was an analytical observational study with cross sectional design. The population for this study were acute ischemic stroke patients at NTB Genereal Hospital. The collected data were analyzed by Spearman correlation test.

Results: Approximately 52 participants were enrolled in this study with mean age was $59.79 \pm 8.65$ years old. Hypertension was a common modifiable risk factor identified in more than $94.2 \%$ participant. The mean of neutrophil lymphocyte ratio was $3.94 \pm 2.96$ and mean of infarct volume was $13.96 \pm 37.26 \mathrm{~cm}^{3}$. There was correlation between RNL and cerebral infract volume $(r=+0.351 ; p=0.023)$.
\end{abstract}

Discussions: Higher lymphocyte neutrophil ratio in acute ischemic stroke patients would result in an increase of brain infarct volume.

Keyword: Infarct volume, ischaemic stroke, neutrophil lymphocyte ratio

\section{ABSTRAK}

Pendahuluan: Inflamasi memegang peranan penting dalam patofisiologi stroke. Salah satu subtipe dari sel leukosit yang paling awal menginfiltrasi ke area iskemia di otak adalah neutrofil. Rasio neutrofil limfosit (RNL) merupakan faktor independen terhadap beratnya penyakit jantung koroner dan sebagai prediktor luaran klinis yang buruk pada penderita penyakit jantung koroner yang menjalani angiografi. Nilai RNL dapat menjadi faktor prognostik pada penderita stroke iskemik. Nilai RNL juga bisa digunakan dalam memprediksi ukuran infark namun belum dilakukan penelitian hingga saat ini.

Tujuan: Mengetahui korelasi RNL dengan volume infark serebri pada penderita stroke iskemik akut.

Metode: Penelitian analitik observasional dengan desain potong lintang terhadap pasien stroke iskemik akut di RSUP NTB. Data yang terkumpul dianalisis dengan uji korelasi Spearman.

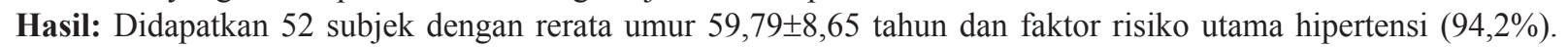

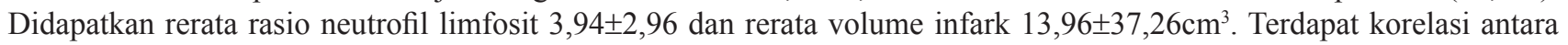
RNL dengan volume infark serebri ( $r=+0,351 ; \mathrm{p}=0,023)$.

Diskusi: Semakin tinggi nilai rasio neutrofil limfosit mengakibatkan semakin luasnya volume infark serebri pada penderita stroke iskemik akut.

Kata kunci: Rasio neutrofil limfosit, stroke iskemik, volume infark

*Departemen Neurologi FK Universitas Mataram/RSUD Propinsi NTB; **Departemen Radiologi FK Universitas Mataram/RSUD Propinsi NTB. Korespondensi: ilsahunaifi@unram.ac.id.

\section{PENDAHULUAN}

Stroke merupakan penyebab kematian dan kecacatan utama di seluruh RS di Indonesia dengan angka kematian akibat stroke sekitar 15\% dan tingkat kecacatan mencapai 65\%. ${ }^{1}$ World Health Organization memperkirakan sekitar 15 juta orang terkena stroke di seluruh dunia, 5 juta orang meninggal, dan sisanya mengalami kecacatan permanen. ${ }^{2}$
Proses inflamasi berperan penting dalam patofisiologi stroke iskemik akut. Proses inflamasi tersebut melibatkan aktivasi endotel, terjadinya kerusakan sawar darah otak, akumulasi mediator inflamasi, infiltrasi leukosit dan platelet dalam jumlah yang besar. Proses inflamasi ini berkembang dalam beberapa jam dan berperanan penting dalam kerusakan akibat iskemik. ${ }^{3}$ 
Inflamasi dapat mengakibat efek positif maupun negatif terhadap luaran neurologis. Iskemia otak memicu terjadinya trauma sekunder berupa inflamasi sebagai respon terjadinya kematian sel yang diikuti oleh pembentukan reactive oxygen spesies (ROS). Neutrofil merupakan sel yang paling awal masuk ke dalam iskemia otak. Pada penelitian hewan coba, neutrofil pertama kali terlihat dalam 4-6 jam dan menetap setelah 12 jam. Penelitian menunjukkan bahwa dengan melakukan penghentian neutrofil ke dalam otak dapat memperbaiki defisit neurologis pada pasien stroke. Hal ini menunjukkan bahwa neutrofil mempunyai efek negatif terhadap luaran pasien stroke. ${ }^{4-5}$

Penelitian lain menunjukkan neutrofil melakukan infiltrasi ke area iskemik dalam waktu 1 sampai 3 hari. ${ }^{6}$ Sel limfosit mampu melakukan infiltrasi ke dalam iskemik otak lebih lambat dibandingkan neutrofil dimana puncaknya pada hari ke-3-6 stroke. ${ }^{4}$

Neutrofil mampu memproduksi berbagai kemokin dan sitokin yang bersifat proinflamasi dan proaterogenik, seperti interleukin-1 alfa (IL-1 $\alpha$ ), IL$1 \beta$, IL-3, IL-6, IL-10, IL-12, IL-18, tumor necrotic factor-alfa (TNF- $\alpha)$. Neutrofil memicu pelepasan monocyte chemoattractant protein-1 (MCP-1) yang berfungsi sebagai kemokin proinflamasi, memacu pengerahan monosit, memacu proliferasi dan migrasi sel otot polos, serta bersifat proaterogenik. Neutrofil juga melepaskan growth regulated oncogen (GR) alfa, beta, dan gamma yang berfungsi sebagai kemokin proinflamasi, memicu proliferasi sel endotel, sel otot polos, dan bersifat proaterogenik. ${ }^{4-5}$

Oleh karena itu, akumulasi neutrofil pada daerah infark serebri berkaitan dengan derajat kerusakan jaringan otak dan luaran neurologis yang buruk setelah mengalami stroke iskemik. ${ }^{4-5} \mathrm{Hal}$ ini bisa dinilai dari rasio neutrofil limfosit (RNL) sebagai petanda efek negatif dari peningkatan kadar neutrofil yang menunjukkan inflamasi akut dan penurunan kadar limfosit yang menunjukkan adanya stres fisiologis, dan dapat menjadi prediktor risiko stroke. ${ }^{7}$ Nilai normal RNL pada manusia dewasa sehat berkisar antara 0,78-3,53. ${ }^{8}$ Rasio ini merupakan faktor independen terhadap beratnya penyakit jantung koroner dan berbagai penyakit kanker. ${ }^{8}$

RNL menggambarkan respons imun innate dan adaptif dari darah perifer. Peningkatan RNL menunjukkan peningkatan kadar neutrofil dan penurunakan kadar limfosit yang mengindikasikan ketidakseimbangan antara inflamasi sentral yang diinduksi oleh stroke dan inflamasi perifer. Target utama inflamasi adalah kerusakan sawar darah otak, sehingga berbagai sel inflamasi terutama neutrofil akan menginfiltrasi ke dalam lesi serta menginduksi stres oksidatif dan kerusakan sawar darah otak. ${ }^{9} \mathrm{RNL}$ mudah dihitung berdasarkan hasil hitung sel darah putih pada saat masuk RS sebagai penanda regulasi imunitas dan potensial menjadi penanda prognostik pada penderita stroke akibat oklusi pembuluh darah besar. ${ }^{10}$

Pada stroke iskemik akut, nilai RNL dapat menjadi faktor prognostik. Semakin besar nilai RNL, maka prognosisnya akan semakin buruk dalam 3 bulan pascastroke. ${ }^{11}$ Selain itu nilai RNL juga bisa digunakan dalam memprediksi ukuran infark, namun belum ada yang melakukan penelitian. ${ }^{3}$

\section{TUJUAN}

Untuk mengetahui korelasi antara rasio neutrofil limfosit (RNL) dengan volume infark serebri pada penderita stroke iskemik akut.

\section{METODE}

Penelitian ini dilakukan secara potong lintang terhadap pasien stroke iskemik akut yang dirawat di RSUD Propinsi NTB antara bulan April sampai September tahun 2016. Kriteria inklusi adalah pasien stroke iskemik serangan pertama dengan awitan $\leq 72$ jam, usia 35-65 tahun, telah dilakukan CT scan kepala tanpa kontras pada hari pertama masuk RS, dan bersedia mengikuti penelitian. Adapun kriteria eksklusi adanya demam $\geq 38^{\circ} \mathrm{C}$, gangguan hematologi, keganasan, atau mengkonsumi obat imunosupresan, seperti kortikosteroid dan kemoterapi.

Perhitungan rasio neutrofil dan limfosit dilakukan secara manual dengan membandingkan kadar neutrofil dan limfosit serum. Perhitungan volume infark menggunakan metode manual tracing of the perimeter dengan menandai perimeter infark secara 
manual pada CT scan kepala. ${ }^{12}$ Hasil perhitungan volume infark serebri dihitung dalam $\mathrm{cm}$ kubik $\left(\mathrm{cm}^{3}\right)$. CT scan kepala dilakukan pada hari pertama saat masuk RS dengan onset stroke $\leq 3$ hari (72 jam).

Derajat keparahan stroke dinilai dengan menghitung skala National Institute Health Stroke Scale (NIHSS) yang diklasifikasikan menjadi ringan $(\leq 4)$, sedang (5-15), dan berat $(>15)$. Analisis statistik menggunakan uji korelasi Spearman.

\section{HASIL}

Didapatkan 52 subjek penelitian (Tabel 1) yang memenuhi kriteria inklusi dan eksklusi. Rerata umur subjek penelitian adalah 59,79 $\pm 8,65$ tahun dengan faktor risiko utama stroke berupa hipertensi $(94,2 \%)$ dan merokok $(65,4 \%)$. Mayoritas subjek datang dalam keparahan stroke derajat sedang $(78,8 \%)$, rerata rasio neutrofil limfosit $3,94 \pm 2,96$; dan rerata volume infark $13,96 \pm 37,26 \mathrm{~cm}^{3}$.

Tabel 1. Karakteristik Subjek Penelitian $(n=52)$

\begin{tabular}{|c|c|c|}
\hline Karakteristik & Rerata (SD) & n (\%) \\
\hline Usia & $59,79(8,65)$ & \\
\hline \multicolumn{3}{|l|}{ Jenis Kelamin } \\
\hline - Laki-laki & & $32(61,5)$ \\
\hline - Perempuan & & $20(38.5)$ \\
\hline \multicolumn{3}{|l|}{ Faktor Risiko } \\
\hline - Hipertensi & & $49(94,2)$ \\
\hline - Diabetes melitus & & $18(34,6)$ \\
\hline - Dislipidemia & & $18(34,6)$ \\
\hline - Merokok & & $34(65,4)$ \\
\hline - Lainnya & & $3(5,77)$ \\
\hline \multicolumn{3}{|l|}{ NIHSS } \\
\hline - Ringan & & $11(21,2)$ \\
\hline - Sedang & & $41(78,8)$ \\
\hline - Berat & & $0(0)$ \\
\hline Rasio Neutrofil Limfosit & $3,94(2,96)$ & \\
\hline Volume Infark Serebri $\left(\mathrm{cm}^{3}\right)$ & $13,96(37,26)$ & \\
\hline
\end{tabular}

Volume infark menggambarkan banyaknya kematian sel otak pada stroke iskemik. Rasio neutrofil limfosit dapat memprediksi ukuran volume infark. Berdasarkan uji Spearman, koefisien korelasi antara rasio neutrofil limfosit dengan volume infark sebesar 0,315 ( $\mathrm{p}=0,023)$. Hal ini menunjukkan bahwa korelasi antara rasio neutrofil limfosit bersifat cukup dan bermakna secara statistik, artinya semakin tinggi rasio neutrofil limfositnya, semakin luas volume infark serebri.

\section{PEMBAHASAN}

Penelitian ini mendapatkan total kelompok usia 55-64 dan 65-74 tahun sebesar 79,1\% dengan lakilaki lebih banyak dibandingkan perempuan, selaras dengan angka kejadian stroke pada riset kesehatan dasar Departemen Kesehatan Republik Indonesia. ${ }^{1}$ Hipertensi merupakan faktor risiko utama terjadinya stroke di Indonesia, sesuai dengan penelitian ini bahwa lebih dari $90 \%$ subjek memiliki faktor risiko hipertensi, diikuti diabetes melitus dan dislipidemia.

Hipertensi menyebabkan kerusakan endotel yang merupakan predisposisi terjadinya iskemia serebri dan stroke. ${ }^{11-12}$ Hipertensi juga menyebabkan aterosklerosis dengan dimediasi oleh peptida vasoaktif, yakni angiotensin II (Ang II) dan endotelin-1 (ET-1). Endotelin-1 mengakibatkan terjadinya vasokonstriksi, aktivasi leukosit, dan platelet serta proliferasi selular. ${ }^{13-14}$

Rasio neutrofil limfosit dapat digunakan untuk memprediksi ukuran infark. ${ }^{3}$ Penelitian ini menunjukkan korelasi yang positif antara RNL dengan volume infark serebri $(r=+0,315, p=0,023)$, yaitu semakin tinggi rasio neutrofil limfositnya maka makin luas volume infarknya. Volume infark menentukan berat ringannya defisit neurologis pada penderita stroke iskemik akut. ${ }^{15}$ Rerata nilai RNL penelitian ini sebesar 3,9 dengan titik potong (cut off point) sebesar 4 pada berbagai jenis stroke iskemik, yang berarti semakin tinggi rasio RNL berkaitan erat dengan mortalitas penderita stroke iskemik. ${ }^{9}$

Keterbatasan penelitian ini adalah pemeriksaan RNL dan penghitungan volume infark hanya dilakukan di awal saat penderita masuk RS.

\section{KESIMPULAN}

Rasio neutrofil limfosit dapat digunakan untuk memprediksi ukuran infark, semakin tinggi rasionya maka makin luas volume infarknya.

\section{DAFTAR PUSTAKA}

1. Departemen Kesehatan Republik Indonesia. Riset Kesehatan Dasar. 2013. h.91-4.

2. World Health Organization. The atlas of heart disease and stroke; 2013.

3. Tokgoz S, Kayrak M, Akpinar Z, Seyithanoqlu A, Guney F, Yuruten B. Neutrophil lymphocyte 
ratio as a predictor of stroke. J Stroke Cerebrovasc Dis. 2013;22(7):1169-74.

4. Kawabori M, Yenari MA. Inflammatory responses in brain ischemia. Curr Med Chem. 2015;22(10):125877.

5. Herz J, Sabellek P, Lane TE, Gunzer M, Hermann DM, Doeppner TR. Role of neutrophils in exacerbation on brain injury after focal cerebral ischemia in hyperlipidemic mice. Stroke. 2015;46(10):2916-25.

6. Cuartero MI, Ballesteros I, Moraga A, Nombela F, Vivancos J, Hamilyon JA, dkk. N2 neutrophil, novel player in brain inflammation after stroke modulation by the PPAR $\gamma$ agonist rosiglitazone. Stroke. 2013;44(12):3498-508.

7. Yuksel IO, Koklu E, Arslan S, Cagirci G, Goksu EO, Koc P, dkk. Association of neutrophil/lymphocyte ratio with plaque morphology in patients with asymptomatic intermediate carotid artery stenosis. Korean Circ J. 2016;46(5):699-705.

8. Forget P, Khalifa C, Defour JP, Latinne D, Van-Pel $\mathrm{MC}$, De-Kock M. What is the normal value of the neutrophil-to-lymphocyte ratio? BMC Res Notes. 2017;10(11):12.

9. Song SY, Zhao XX, Rajah G, Hua C, Kang RJ, Han Yp, dkk. Clinical significance of baseline neutrophil to lymphocyte ratio in patients with ischemic stroke or hemorrhagic stroke: an update meta analysis. Front Neurol. 2019;10:1032.
10. Goyal N, Tsivgoulis G, Chang JJ, Malhotra K, Phandi A, Ishfaq MF, dkk. Admission neutrophil to lymphocyte ratio as a prognostic biomarker of outcome in large vessel occlusion stroke. Stroke. 2018;49(8):1985-7.

11. Dinh QN, Chrissobolis S, Diep H, Chan CT, Ferens $\mathrm{D}$, Drummond DR, dkk. Advanced atherosclerosis is associated with inflammation, vascular dysfunction and oxidative stress, but not hypertension. Pharmacol Res. 2016;116:70-6.

12. Miller AA, Sobey CG. Vascular biology and atherosclerosis of cerebral arteries. Dalam: Mohr JP, Wolf PA, Moskowitz MA, Mayberg MR, Kummer RV, Grotta JC, editor. Stroke: Pathophysiology, diagnosis and management. Edisi ke-5. Philadelphia: Elsevier Saunders; 2011.

13. Zmyslowski A, Szterk A. Current knowledge on the mechanism of atherosclerosis and pro-atherogenic properties of oxysterol. Lipids Health Dis. 2017;16(1):188.

14. Iturbe BR, Pons $\mathrm{H}$, Johnson RJ. Role of the immune system in hypertension. Physiol Rev. 2017;97(3):1127-64.

15. Han J, Bae HJ, Wong LKS. Pathophysiology and mechanism whereby hypertension may cause stroke. Dalam: Aiyagi V, Gorelick PB, editor. Hypertension and stroke: pathophysiology and management. New York: Humana Press; 2011. h. 77-94. 